\title{
Stages in the Incorporation of
}

\section{Fatty Acids into Red Blood Cells}

\author{
Stephen B. Shohet, David G. Nathan, and Manfred L. Karnovsky \\ From the Departments of Medicine and Biological Chemistry, Harvard Medical \\ School; Peter Bent Brigham Hospital, and Children's Hospital Medical Center, \\ Boston, Massachusetts 02215
}

A B S TRACT Mature human erythrocytes were incubated with ${ }^{14} \mathrm{C}$-labeled palmitic acid bound to crystalline human albumin. Energy-dependent incorporation of the labeled palmitic acid into cell membrane phospholipids occurred, and various stages in this incorporation were defined.

Initially the palmitic acid was rapidy transferred from the albumin to a "superficial" membrane pool of free fatty acid (F-1), which was removable when the cells were washed with defatted albumin. This process was independent of red cell metabolism.

The labeled fatty acid then passed into a second "deeper" membrane pool of free fatty acids (F-2), which was not extractable with albumin. This process was energy-dependent and proceeded at a slower rate than the initial transfer from albumin to $\mathrm{F}-1$.

Ultimately the labeled fatty acid was incorporated into phosphatides (PL). This process also was dependent upon cellular metabolism.

The kinetics of pulse label studies suggest that the processes observed were sequential and that precursor-product relationships exist between the F-1 and F-2 pools and the F-2 and PL pools.
From the size and specific activities of these pools, calculations of the extent of phospholipid turnover were made. An approximate figure of $2 \% / \mathrm{hr}$ or $30 \mathrm{nmoles} / \mathrm{ml}$ of packed red blood cells per $\mathrm{hr}$ was obtained. The figure was further calculated to represent an energy cost to the red blood cell of approximately $5 \%$ of the energy available from glycolysis.

\section{INTRODUCTION}

The incorporation of unesterified fatty acids of the external medium into the phosphatides of erythrocyte membranes was first noted by Oliveira and Vaughan 5 yr ago (1). They found, using erythrocyte ghosts as experimental objects, that this incorporation was primarily into phosphatidylcholine and that ATP and coenzyme A were required. Subsequently Mulder, Van Den Berg and Van Deenen suggested that two biochemical pathways could be operative in the final stages of this incorporation (2). These pathways are: (a) Insertion of fatty acids (activated as acyl CoA) into preformed lysophosphatidylcholine by the pathway originally described by Lands (3).

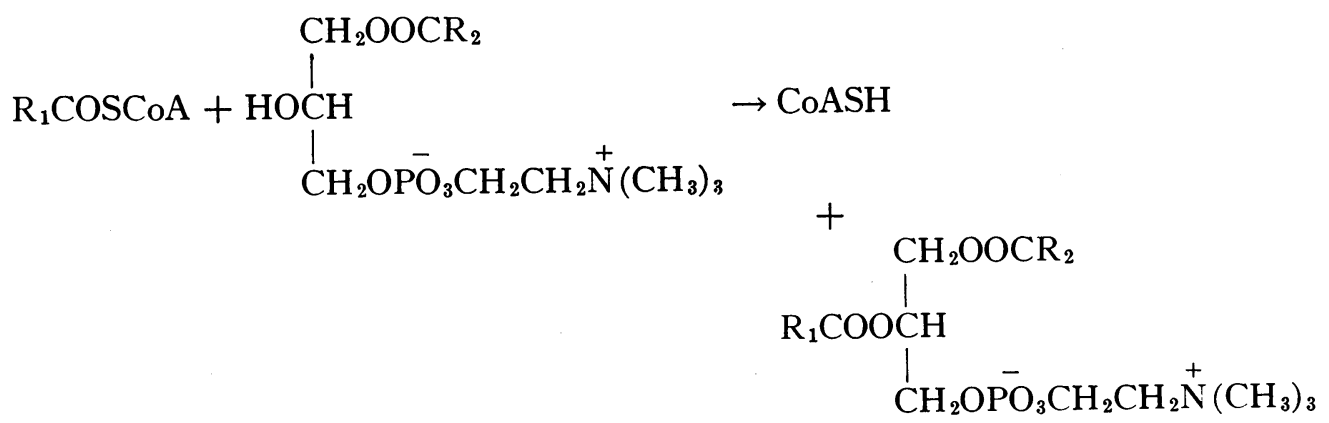

Part of this material has been presented previously in abstract form: J. Clin. Invest. 1967. $46: 1117$. Address requests for reprints to Dr. Stephen B. Shohet, 721 Huntington Avenue, Boston, Mass. 02215. Received for publication 18 September 1967 and in revised form 11 December 1967. 
(b) Transesterification between two lysophosphatidylcholine molecules to form one phosphatidylcholine and one glycerophosphorylcholine, as described by Erbland and Marinetti (4).

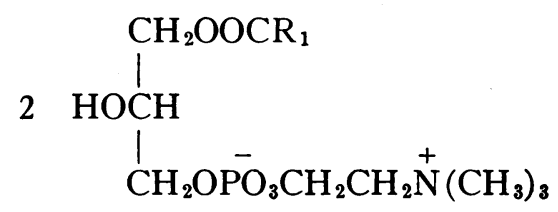

Mulder and Van Deenen (5) later presented convincing evidence that in the presence of adequate CoA and ATP, the first reaction predominates, whereas without these cofactors the latter is the major pathway. Elsbach using white blood cells showed that at physiological $\mathrm{pH}$ the acylation pathway was dominant, whereas at lowered $\mathrm{pH}$ the transesterification pathway became important (6). Recently Donabedian and Karmen (7) have studied the relative rates of transfer of different fatty acids to red cells and their subsequent rates of incorporation into phospholipid. Because of the importance of phosphatides in membrane structure and because the metabolism of these compounds may well be important in membrane function, we believed that it was warranted to investigate in further detail the incorporation of fatty acids into red cell membranes, and particularly to examine the events immediately antecedent to this incorporation.

The purpose of this report is thus to describe experiments defining the stages in the transfer of fatty acids from extracellular albumin to human red cell phospholipids, and to estimate the energy required. The process will be shown to involve three metabolic pools of fatty acids. These pools have been designated as follows: (1) a pool of unesterified fatty acid, which can be removed from the cell by washing with defatted albumin (F-1 pool) ; (2) a pool of unesterified fatty acid which is not extractable by defatted albumin and which might be considered "deeper" in the membrane (F-2 pool); and (3) the fatty acids bound in ester linkages in membrane phosphatides (PL pool).
The results suggest that $(a)$ transfer of fatty acids from albumin into the "superficial" red cell pool $(\mathrm{F}-1)$ is rapid and independent of cellular energy, $(b)$ the subsequent transfer of fatty acids

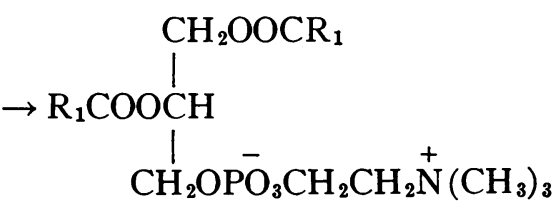<smiles>C[N+](C)(C)CC[P+](=O)OCC(O)CO</smiles>

from this pool to the "deeper" membrane pool (F-2) is less rapid and requires metabolic energy, and $(c)$ uptake into the phospholipids (PL) proceeds from F-2 and is also energy dependent. The phosphatides involved in this process are phosphatidylcholine and phosphatidylethanolamine (ca. $95 \%$ of total incorporation into $\mathrm{PL}$ is concerned with these entities).

Although we lay particular stress on red blood cells and aspects of the maintenance of red cell membranes, phenomena such as those reported below have, of course, more general implications. For example, Spector and Steinberg have studied analogous situations in Ehrlich ascites cells (8-10).

\section{METHODS}

A. Materials. Crystallized human serum albumin was obtained from Dade Reagents Inc., Miami, Fla. Palmitic acid-1 $1{ }^{14} \mathrm{C}$, palmitic acid-9,10- ${ }^{8} \mathrm{H}$ and ${ }^{125} \mathrm{I}$ were obtained from New England Nuclear Corporation, Boston, Mass. All other reagents used were reagent grade. Polyvinylpyrrolidone (NP-K60) was obtained from the General Aniline and Film Corporation, New York. Silica Gel G for separation of neutral lipids and Silica $\mathrm{Gel} \mathrm{H}$ for phospholipid separations were obtained from CAMAG Chemicals, Muttenz, Switzerland.

$B$. Cell collection and preparation. Peripheral venous blood was obtained with plastic syringes from normal human subjects. Heparin $(3 \mathrm{U} / \mathrm{ml})$ was added to prevent coagulation. Red cells were separated from plasma and white cells as follows. The freshly drawn blood was centrifuged at $300 \mathrm{~g}$ for $10 \mathrm{~min}$ in siliconized glass tubes; at the end of this time the white cell- and platelet-rich plasma was removed along with the top $10 \%$ of the red cell mass; subsequently, the bulk of the red cells was resuspended in 3 volumes of Krebs-Henseleit buffer (KHB) $\mathrm{pH} 7.4$ (11) with $8 \mathrm{~mm}$ glucose, and centri- 
fuged at $600 \mathrm{~g}$; again the supernatant fluid and $10 \%$ of the residual red blood cells were removed. After this process was repeated once more, the residual white blood cell count on a red cell suspension reconstituted to an hematocrit of $50 \%$ was always less than 400 cells $/ \mathrm{mm}^{8}$, and there were usually less than 200 white blood cells $/ \mathrm{mm}^{8}$.

C. Preparation of defatted albumin and replacement of fatty acids on albumin. Crystalline human serum albumin was defatted by the method of Goodman (12). After lyophilization a chloroform-methanol extract was made $(13,14)$, and free fatty acids were assayed by the method of Dole and Meinertz (15). In our hands, $92-94 \%$ of the free fatty acid was removed by Goodman's procedure.

The fatty acids of albumin treated in this way could then be replaced with labeled fatty acids as follows. ${ }^{1}$ $100 \mathrm{ml}$ of KHB containing $800 \mathrm{mg}$ of the defatted albumin preparation was placed in an $800 \mathrm{ml}$ Erlenmeyer flask. $15 \mathrm{ml}$ of heptane containing $4 \mathrm{mg}$ of ${ }^{14} \mathrm{C}$ - or ${ }^{8} \mathrm{H}$-labeled palmitic acid was gently layered upon this solution, and the air was displaced with nitrogen. The flask was closed and gently rocked for $36 \mathrm{hr}$ at room temperature. The speed was controlled so that interfacial contact was maximal without production of emulsions or froth. After $36 \mathrm{hr}$ the layers were separated, and the albumin mixture was filtered through No. 42 Whatman paper. Aliquots of both the albumin-containing and heptane layers were then taken for counting in a liquid scintillation counter in Buhler's toluene solution (16). At this point $94-96 \%$ of the added palmitic acid was in the aqueous layer, and FFA had been restored to the albumin to about $70 \%$ of the starting level. ${ }^{2}$ The albumin-containing layer was dialyzed against fresh buffer. It was convenient to add small volumes of this component to the final incubation mixture; concentration was effected by ultrafiltration. The albumin with fatty acid attached is referred to as Alb-FA.

D. Incubation of red cells with fatty acid. The red cells prepared as above were resuspended to a final hematocrit of $50 \%$ in $\mathrm{KHB}$ with ca. $8 \mathrm{~mm}$ glucose and albumin-fatty acid complex (Alb-FA, $200 \mathrm{mg} / 100 \mathrm{ml}$ ). The fatty acid concentration was thus approximately 45 $\mu \mathrm{Eq} /$ liter. Duplicate cell suspensions were incubated in small $(25 \mathrm{ml})$ stoppered siliconized flasks at $37^{\circ} \mathrm{C}$ or at $4^{\circ} \mathrm{C}$ with gentle reciprocating agitation (40 cycles $/ \mathrm{min}$; excursion 2 inches).

Aliquots of these suspensions were taken for analysis

1 The authors are grateful to Dr. Arthur Karmen who originally instructed us in this method. We used this method because we thought it might have the advantage, compared to the more usual method of adding the potassium salts of the fatty acids to the albumin, of reducing the possibility of formation of particulate entities. The method allowed the preparation of albumin-fatty acid complexes of very high specific activity and high saturation, with little waste of radioactive material.

2 This corresponded to approximately $1.5 \mathrm{mEq}$ of free fatty acid per mmole of crystalline albumin. In other studies we have found $1.5-3.2 \mathrm{mEq}$ of free fatty acid per mmole protein on preparations of previously untreated human albumin from several different sources. at various time intervals after the incubation was started. These were immediately pipetted into 10 volumes of normal saline at $4^{\circ} \mathrm{C}$ and spun in a refrigerated centrifuge at $500 \mathrm{~g}$ for $3 \mathrm{~min}$. The sedimented cells were washed four times with 10 volumes of cold isotonic $\mathrm{NaCl}$ solution. No further radioactivity was removable by washing with isotonic saline.

For all determinations below, a small correction factor was introduced $(5-10 \%)$ for losses of cells at the various stages. This correction was made by measuring total hemoglobin on aliquots.

E. Removal of unesterified fatty acids with albumin $(F-1$ pool $)$. The washed red cells from $\mathrm{D}$ above were then usually subjected to a series of five washes at $20^{\circ} \mathrm{C}$ with defatted human albumin solution $(1 \mathrm{~g} / 100 \mathrm{ml})$ prepared as described above. Radioactivity was apparent in the first three washes, but no further activity was removed after the fourth wash. After lyophilization of the albumin-containing washings, the F-1 lipids were extracted with chloroform-methanol and analyzed by thin-layer chromatography (see below). In this albumin removable pool, over $96 \%$ of the activity was in unesterified fatty acids with only $2-3 \%$ in phosphatides and $1-2 \%$ unidentified.

F. Extraction and assay of more tightly bound fatty acids and phosphatides ( $F-2$ and $P L$ pools). Lipids were now extracted from the red cells with aqueous isopropanol and chloroform by the method of Rose and Oklander (17). Two washes of the extract with $0.05 \mathrm{~N} \mathrm{KCl}$ were performed to remove residual nonlipid contaminants. Samples were taken from these lipid extracts for counting, and then the solutions were evaporated to dryness under nitrogen at $50^{\circ} \mathrm{C}$. The lipids were taken up in a small volume (ca. $0.1 \mathrm{ml}$ ) of chloroform-methanol (2:1). Thin-layer chromatography was performed on 16-inch long glass plates coated with Silica Gel $\mathrm{H}$ to separate the phospholipid classes. The developing solvent for phosphatides (PL pool) was the aqueous acetic acid-chloroformmethanol system described by Skipski, Peterson, and Barclay (18). Identification of phosphatide spots was achieved with ninhydrin (19) for phosphatidylethanolamine and Dragendorff's reagent for phosphatidylcholine (20). Identification of neutral lipid components was made by rechromatography of the neutral lipids. These lipids were eluted from the above plates with chloroformmethanol and rechromatographed on Silica Gel G with ether-hexane-acetic acid-chloroform as developing solvent (21). Radioactive spots corresponding to free fatty acids, triglycerides, and diglycerides were detected. In samples taken after short incubations, the vast majority (greater than $80 \%$ ) of radioactivity was in free fatty acids. The unesterified fatty acid zone is referred to as the F-2 pool.

G. Determination of specific activity of pools and calculation of transfer between pools. The thin-layer plates were first counted in a Baird-Atomic gas flow strip scanner (model No. RSC-363). When specific activities of various fractions were to be determined, components were eluted (18). Aliquots were than taken for liquid scintillation counting in Buhler's solution and for chemi- 
cal assay. For determination of phosphorus-containing compounds, a minor modification of the colorimetric method of Lowry, Roberts, Leiner, $\mathrm{Wu}$, and Farr for phosphate was used (22). For free fatty acid, Dole's microtitration was employed (15). When the latter method was used, care was taken to filter any residual silica gel from the test solutions, and a blank was performed on a sample of the same amount of silica gel as that from which the lipid was eluted.

Fatty acid transfer between the pools (F-1, F-2, and PL) was estimated by dividing the number of counts detected in a given pool by the specific activity of the material in the preceding pool, e.g., transfer from F-1 into $\mathrm{F}-2$ (in $\mu$ moles) $=\mathrm{cpm}$ in $\mathrm{F}-2 / \mathrm{SA}$ of $\mathrm{F}-1$ (all specific activities [SA] as cpm per $\mu$ mole FA). All calculations of fatty acid transfer with the exception of the initial transfer from albumin to F-1 were made after $1 \mathrm{hr}$ of incubation with the standard incubation system and with a large excess of Alb-FA (ca. 25 times the F-1 pool). Calculation of fatty acid transfer from albumin to F-1 was made under the same conditions but after $5 \mathrm{~min}$ of incubation, since this phenomenon was only briefly linear (see below).

\section{RESULTS}

A. Effect of added white blood cells. On one occasion after the red cells had been obtained in the usual way, graded amounts of a white blood cell suspension obtained from the same donor were added to separate incubation systems. These white blood cells were obtained from the leukocyte-rich serum produced in the first centrifugation of the red blood cells. The white cells were washed twice in 20 volumes of Krebs-Henseleit buffer containing glucose, after gentle centrifugation $(500 \mathrm{~g}$ for $8 \mathrm{~min}$ ) in siliconized tubes. Smears taken after preparation showed a differential count of $45 \%$ polymorphonuclear leukocytes (PMN), 37\% lymphocytes, $8 \%$ mononuclear cells and $10 \%$ swollen or smudge cells. Smears on the donors of the fresh blood showed 55\% PMN, 45\% lymphocytes, and $5 \%$ monocytes. Fig. 1 shows that the graded addition of up to 2000 white cells $/ \mathrm{mm}^{3}$ in the final incubation mixture did not significantly change the character or extent of the incorporation noted. Above 3000 white blood cells $/ \mathrm{mm}^{3}$, a small increment in phospholipid activity could be detected. As noted in the Methods section, white cell counts were below 400 cells $/ \mathrm{mm}^{3}$ in all subsequent incubations of red blood cells.

B. Gross uptake of fatty acid into lipid classes. The uptake of palmitic acid- $-{ }^{14} \mathrm{C}$ into lipid classes extracted from cells incubated for $1 \mathrm{hr}$ with

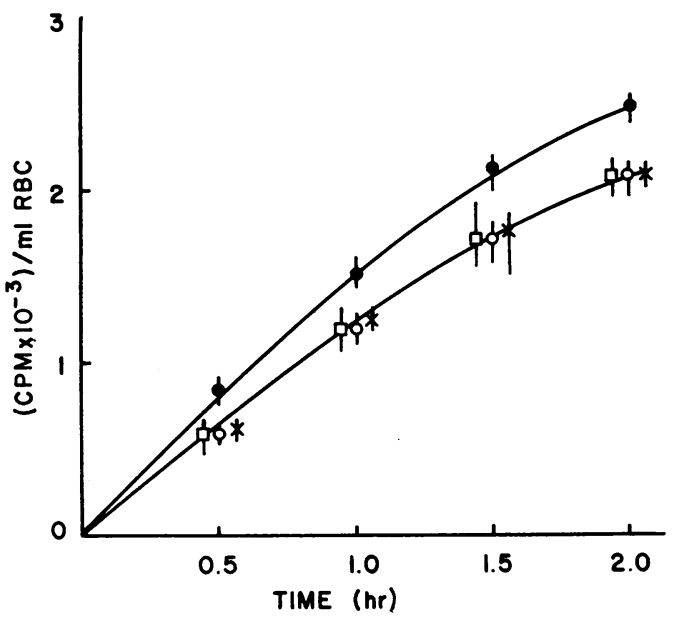

Figure 1 Effect of added white blood cells on incorporation of ${ }^{14} \mathrm{C}$-labeled palmitic acid into phosphatides of red blood cell suspensions. All points are averages of four concurrent incubations. Ranges are indicated by the brackets. Points for various white blood cell concentrations were determined at the same times, but for clarity, they have been displaced slightly in the lower curve. $\bigcirc$, no added white blood cells; $\times, 500$ white blood cells added per $\mathrm{mm}^{\mathbf{3}} ; \square, 2000$ white blood cells added per $\mathrm{mm}^{3}$; - 3000 white blood cells added per $\mathrm{mm}^{3}$. See Results, section A for further details.

Alb-FA-14C followed by saline washes, but without washes with defatted albumin, is shown in Table I, A. As shown in Fig $2 a$ and $b$ the rate of incorporation into phosphatides was almost constant for at least $3 \mathrm{hr}$, but incorporation into the total free fatty acids (F-1 and F-2) did not increase significantly after $90 \mathrm{~min}$. Because of the large amount of activity present as free fatty acid in the nonphosphatide lipids (Table I, A), we wished to define the disposition of the free fatty acids of the erythrocyte. Thus, red cells incubated with Alb-FA- ${ }^{14} \mathrm{C}$ were washed not only with saline (as in this section) but also with defatted albumin as described in Methods section E. The results appear below.

C. Uptake into fatty acid pool not extractable with albumin and into the phospholipid pool (F-2 and $P L)$. The uptake of palmitic acid- ${ }^{14} \mathrm{C}$ into lipid classes extracted from cells incubated for $1 \mathrm{hr}$ with Alb-FA- ${ }^{14} \mathrm{C}$, followed by washing with isotonic saline and with defatted albumin, is shown in Table I, B. Occasionally red cells were prepared in the usual fashion except that glucose was omitted from all washing and resuspension steps. 
TABLE I

Radioactive Counts Obtained from Chromatograms of Extracts of Red Cell Lipids after Various Incubation and Washing Procedures

\begin{tabular}{|c|c|c|c|c|c|}
\hline Component & Zone & $\begin{array}{c}\text { A } \\
37^{\circ} \mathrm{C} \text { incuba- } \\
\text { tion, after } \\
\text { saline washes }\end{array}$ & $\begin{array}{c}\text { B } \\
37^{\circ} \mathrm{C} \text { incuba- } \\
\text { tion, after } \\
\text { saline and } \\
\text { albumin washes }\end{array}$ & $\begin{array}{c}\text { C } \\
4^{\circ} \mathrm{C} \text { incuba- } \\
\text { tion of ATP- } \\
\text { depleted cells, } \\
\text { after saline } \\
\text { washes }\end{array}$ & $\begin{array}{c}\text { D } \\
4^{\circ} \mathrm{C} \text { incuba- } \\
\text { tion of ATP- } \\
\text { depleted cells. } \\
\text { after saline } \\
\text { and albumin } \\
\text { washes }\end{array}$ \\
\hline & $R_{f *}$ & $c p m$ & $c p m$ & $c p m$ & $c p m$ \\
\hline Nonphosphatide lipids $\ddagger$ & $0.92-1.05$ & $5920( \pm 410)$ & $2200( \pm 160)$ & $3000( \pm 280)$ & $380( \pm 140)$ \\
\hline Phosphatidylcholine & $0.26-0.42$ & $1880( \pm 320)$ & $1700( \pm 400)$ & $190( \pm 40)$ & $150( \pm 40)$ \\
\hline Phosphatidylethanolamine & $0.60-0.77$ & $1300( \pm 160)$ & $1360( \pm 330)$ & $160( \pm 30)$ & $160( \pm 40)$ \\
\hline Unidentified radioactivity $\S$ & - & $240( \pm 100)$ & $300( \pm 70)$ & $170( \pm 100)$ & $60( \pm 30)$ \\
\hline
\end{tabular}

All data are averages of results from four chromatographic plates derived from four separate incubations. Two donors supplied the cells for the experiments. Average deviations from the means are shown in parentheses.

* As range of $R_{f}$ taken.

$\ddagger 80 \%$ of activity in free fatty acids. Columns A and C represent essentially F-1 + F-2, and a small amount of esterified fatty acids. B and D are essentially F-2, plus a small amount of esterfied fatty acids.

$\S$ Remainder of strip.

After final resuspension but before incubation with fatty acid-albumin, the cell suspensions were left overnight at $20^{\circ} \mathrm{C}$ with $1 \%$ added polyvinylpyrrolidone (PVP). The cells were then washed once with isotonic saline before use. This procedure has been shown to reduce red cell ATP stores to less than $10 \%$ of normal..$^{3}$ In studies done with ATP-depleted cells incubated at $4^{\circ} \mathrm{C}$, uptake of palmitic acid- ${ }^{14} \mathrm{C}$ in phospholipid fractions was

3 Nathan, D. G. Unpublished experiments. barely detectable, and the amount of free fatty acid present depended on the type of washing procedure. The results of these studies are shown in Table I,C and D. It is notable that at $37^{\circ} \mathrm{C}$ a significant amount of labeled free fatty acid was present after washes with defatted albumin though less than after washing with saline alone (ca. $\frac{1}{3}$ remaining). Labeled free fatty acid was also present in the ATP-depleted cells incubated at $4^{\circ} \mathrm{C}$ after saline washes alone but no significant
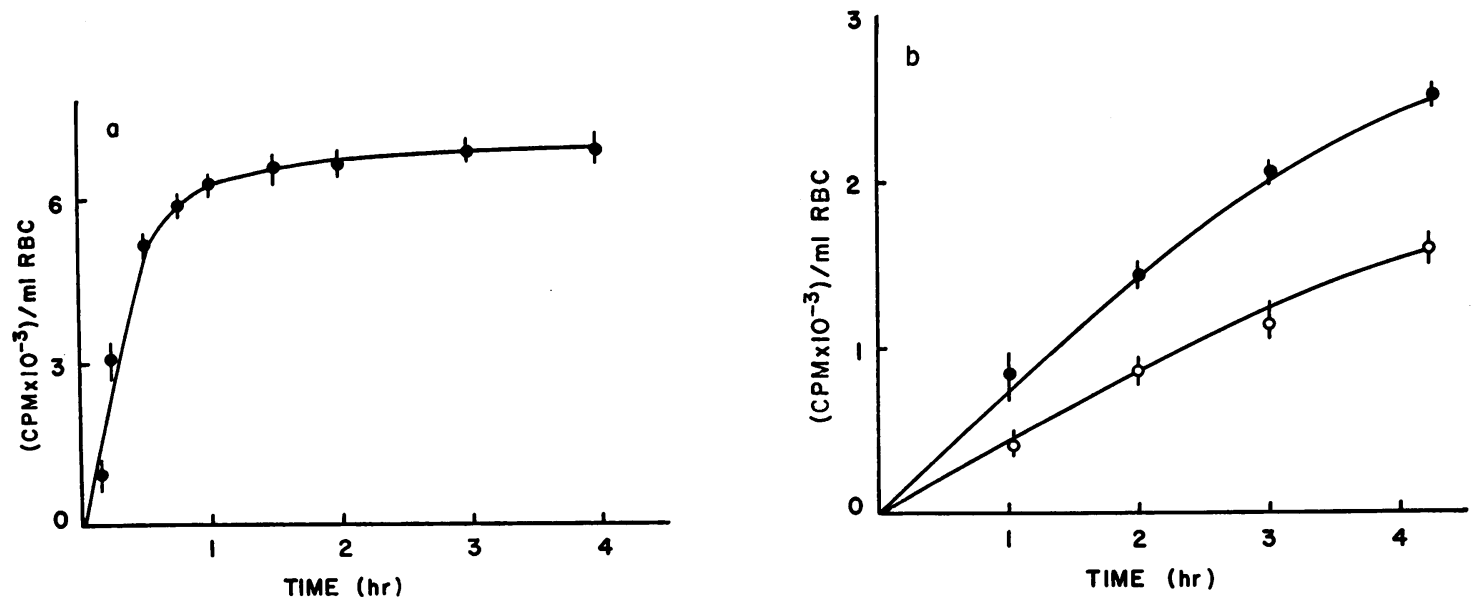

FIGURE $2 a$ and $b$ Time course of incorporation of palmitic acid- $-{ }^{14} \mathrm{C}$ into erythrocyte lipids. All points are averages of two concurrent incubations. The ranges are indicated by the brackets. In the left-hand panel $(2 a)$ the total free fatty acids (F-1 + F-2) are shown. In the right hand panel $(2 b)$, the phosphatides are shown. $\bullet$, phosphatidylcholine; $O$, phosphatidylethanolamine. 
label was found in this fraction after the cells were washed with defatted albumin. Combined with the observation that for cells depleted of ATP and incubated at $4^{\circ} \mathrm{C}$ almost no uptake of free fatty acids into phosphatides could be demonstrated with either washing procedure, these data indicate that the conversion of F-1 to F-2 and of F-2 to $\mathrm{PL}$ depends upon metabolic energy. In other experiments inhibition of new ATP synthesis with $25 \mathrm{~mm}$ sodium fluoride produced intermediate amounts of uptake which were limited to the $1 \mathrm{st} \mathrm{hr}$ of incubation. Thereafter no new uptake of free fatty acid into phosphatide could be detected.

D. Uptake of free fatty acids into the F-1 pool. In addition to confirming the experiments of Oliveira and Vaughn (sections B and C above), the data suggested that two distinct pools of red cell free fatty acid exist. Accordingly, the uptake of free fatty acid into the albumin-extractable F-1 pool was studied in more detail. As shown in Fig. 3, uptake into this pool was rapid and reached an almost constant level after $15 \mathrm{~min}$. The uptake occurred to the same extent and at roughly the same rate at different temperatures and in the absence of ATP stores.

In order to rule out the possibility that incorporation into $\mathrm{F}-1$ was simply passive adsorption

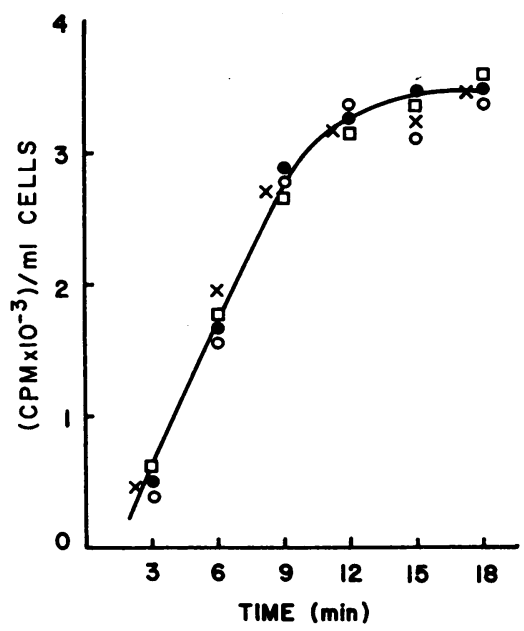

FIgURE 3 Incorporation of palmitic acid- ${ }^{14} \mathrm{C}$ into $\mathrm{F}-1$ (albumin-extractable fatty acid) pool under various conditions. All points represent single samples from concurrent incubations. Points were taken at the same times and are slightly displaced where necessary for clarity. $\square, 20^{\circ} \mathrm{C} ; \bullet, 37^{\circ} \mathrm{C} ; 0,40^{\circ} \mathrm{C} ; \times$, ATP-depleted cells at $37^{\circ} \mathrm{C}$. See Methods, section $\mathrm{E}$, for further details.

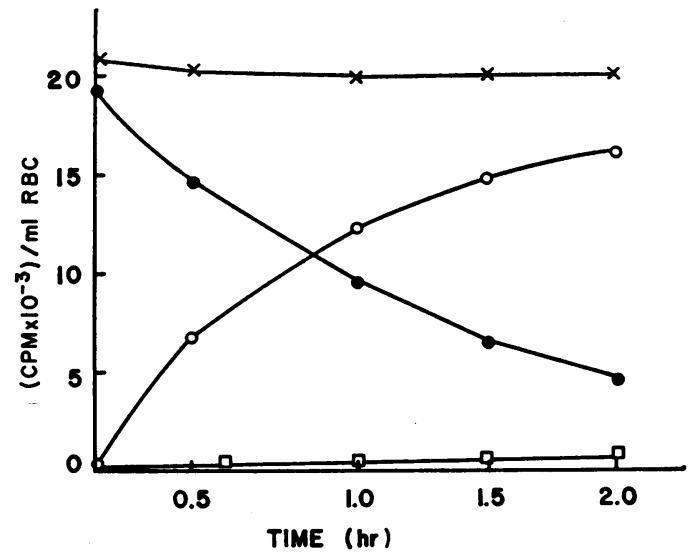

FIGURE 4 Incorporation of ${ }^{8} \mathrm{H}$-labeled palmitic acid into total erythrocyte lipids and attachment of ${ }^{125} \mathrm{I}$-labeled albumin onto erythrocytes. The starting ratio of ${ }^{125} \mathrm{I}$ to ${ }^{8} \mathrm{H}$ counts in the windows selected was $6: 5$. $\bigcirc$, lipid ${ }^{8} \mathrm{H}$ counts; $\bullet$, medium ${ }^{8} \mathrm{H}$ counts; $\square$ cell ${ }^{125} \mathrm{I}$ counts; $X$, medium ${ }^{125} \mathrm{I}$ counts. See Results, section $D$, for further details.

of the whole Alb-FA complex to the cell surface, a doubly labeled experiment was performed by incubating red cells prepared in the usual way in the presence of ${ }^{3} \mathrm{H}$ - and ${ }^{125} \mathrm{I}$-labeled albumin preparation.

Doubly labeled Alb-FA was obtained as follows. Defatted albumin prepared as usual was iodinated with ${ }^{125} \mathrm{I}$ by the method of Reif (23) and was subsequently loaded with tritiated palmitic acid. The uptake of palmitic acid- ${ }^{3} \mathrm{H}$ onto such albumin was identical with uptake onto a noniodinated control sample handled simultaneously. The ratio of activity of ${ }^{125} \mathrm{I}$ to ${ }^{3} \mathrm{H}$ in the final preparation was $6: 5$. Red cells prepared in the usual way were then incubated in the presence of this preparation. Frequent aliquots of both the cells and the incubation media were taken for analyses. After four saline washes, total red cell radioactivity was assayed by the combustion procedure of Nathan, Gabuzda, and Gardner (24). Radioactivity in aliquots of the incubation medium was determined directly in Buhler's solution with a correction for quenching due to small amounts of albumin present. The contributions of ${ }^{3} \mathrm{H}$ and ${ }^{125} \mathrm{I}$ to the total radioactivity were established by counting through two widely separated "windows" on an Ansitron model No. 2 scintillation counter. The results of this experiment are summarized in Fig. 4. Clearly, fatty acid was incorporated into the cell lipids, but 
albumin remained in the medium. Thus, no significant net adsorption of Alb-FA complex to the cell membrane occurred.

E. Relationships between pools. Passage of free fatty acid from the "surface" pool (F-1) to later pools was evaluated as follows. After a brief initial incubation with labeled fatty acid-albumin complex (12 min), the cells were washed in saline four times and then reincubated in Krebs-Henseleit buffer containing 1\% PVP and $8 \mathrm{~mm}$ glucose. Aliquots were taken at various times and analyzed as indicated above. The uptake from F-1 to $(\mathrm{F}-2+\mathrm{PL})$ under various conditions is shown in Fig. 5. At $37^{\circ} \mathrm{C}$, approximately $80 \%$ of the "pulse"-labeled F-1 fraction was converted to $(\mathrm{F}-2+\mathrm{PL})$ in $3 \mathrm{hr}$. This transfer was markedly reduced at $20^{\circ} \mathrm{C}$ and virtually absent in ATPexhausted cells.

Further dissection of the passage of fatty acid to PL is shown in Fig. 6. The design of this incubation was the same as that for Fig. 5. Here the

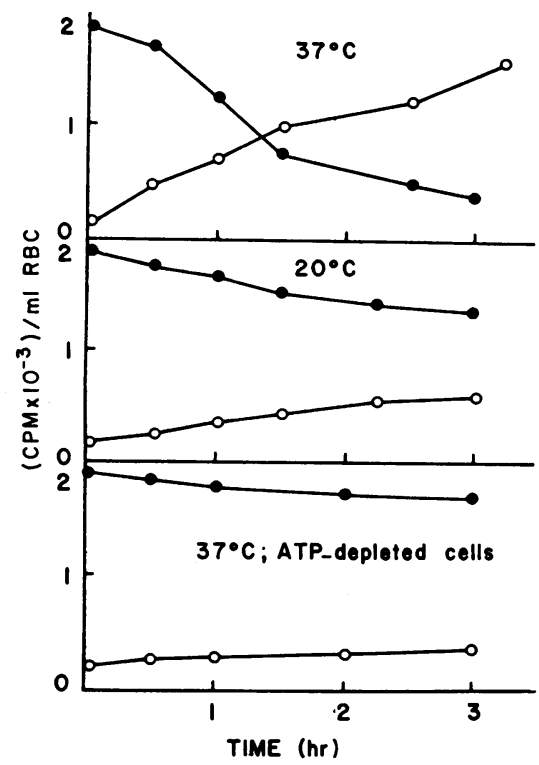

FIgURE 5 Incorporation of ${ }^{14} \mathrm{C}$-labeled palmitic acid from "pulse-labeled" F-1 into F-2 + PL under varying conditions. The cells were saline washed after brief initial incubation with Alb-FA and then reincubated in saline with $1 \%$ polyvinylpyrrolidone and glucose. After this reincubation, aliquots were washed with saline and extracted (washed) with albumin solution at the times indicated on the abscissa. The albumin extracts and the total residual cellular lipids were counted. $\bullet, F-1 ; O, F-2+$ PL. See Results, section $E$, for further details.

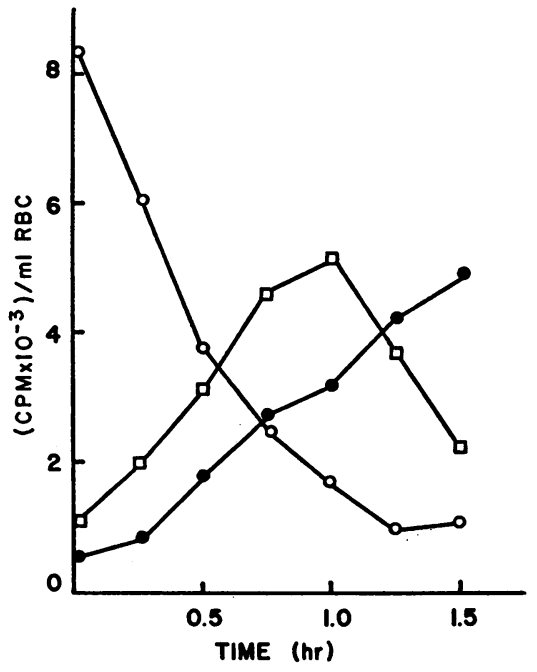

FIGURE 6 Incorporation of ${ }^{14} \mathrm{C}$-labeled palmitic acid from "pulse-labeled" F-1 into F-2 and into PL, separately determined. The cells were saline washed after brief initial incubation with Alb-FA and then reincubated in saline with $1 \%$ polyvinylpyrrolidone + glucose. After this reincubation, aliquots were washed with saline and extracted with albumin at the times indicated on the abscissa. The extracts were counted (F-1), and the residual cellular lipids (F-2 and PL) were separated by thin-layer chromatography and then counted. $O, F-1 ; \square, F-2$; ๑, PL. See Methods, sections E, F, and Results, section A, for further details.

separate conversion of F-1 to F-2 and PL pools is shown. It can be seen that counts in the F-1 pool progressively decrease whereas those in the F-2 pool progressively increase. After approximately $1 \mathrm{hr}$ of incubation, the F-2 pool reaches its maximum activity, and then its activity begins to decrease while that of the phospholipid pool (PL) continually increases.

In order to study "backflow" out of pool F-2 and "forward" flow from F-2 to PL, an experiment establishing a "pulse" label in F-2, then removing the radioactive $\mathrm{F}-1$ fraction and replacing it with unlabeled free fatty acid, was performed as follows. After a brief initial incubation (17 $\mathrm{min}$ ) with extremely active ${ }^{3} \mathrm{H}$-labeled Alb-FA, the red blood cells were washed in saline as usual. They were then washed in five washes of defatted albumin to remove F-1. After this, they were reincubated for $8 \mathrm{~min}$ at $37^{\circ} \mathrm{C}$ in donor plasma saved during the original preparation of the red cells. After the reestablishment of a nonradioactive F-1 pool, the plasma was removed, and the cells were 


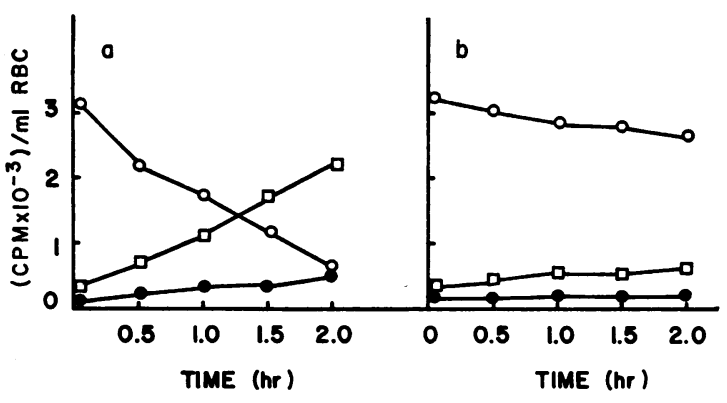

FIgURE $7 a$ and $b$ Incorporation of palmitic acid- ${ }^{3} \mathrm{H}$ into F-1 and PL pools from "pulse-labeled" F-2 pool. The cells were albumin-washed after a brief initial incubation with highly radioactive palmitic acid- ${ }^{3} \mathrm{H}$ albumin. A nonradioactive $F-1$ pool was reestablished with normal donor serum, and the cells were reincubated for various periods as indicated on the abscissa; aliquots were taken and extracted again with albumin. These extracts ( $F-1)$ were counted, and the residual cellular lipids (F-2 and PL) were separated and counted. $a$, the left-hand panel, shows the results of reincubation at $37^{\circ} \mathrm{C} . b$, the right-hand panel, shows the results of reincubation at $4^{\circ} \mathrm{C} . \mathrm{O}, \mathrm{F}-2 ; \bullet, \mathrm{F}-1$; $\square$, PL. See Results, section E, for further details.

again washed once with saline and incubated in buffer. One-half of the cells were incubated in duplicate at $37^{\circ} \mathrm{C}$ with $8 \mathrm{~mm}$ glucose present and one-half were incubated in duplicate at $4^{\circ} \mathrm{C}$ without glucose. Aliquots were removed at various times, and the cells were washed, extracted, and analyzed as usual. The results of this experiment are seen in Fig. $7 a$ and $b$. At $37^{\circ} \mathrm{C}$ the fatty acids in F-2 were steadily transferred to PL, and there was also a slow transfer back to $\mathrm{F}-1$. At $4^{\circ} \mathrm{C}$ these rates were very markedly diminished.

F. Pool size and extent of fatty acid transfer between pools. The size of the various pools and the approximate transfer rates between those pools are indicated in Tables II and III.

TABLE II

Pool Sizes

F-1 $0.19 \pm 0.05 \mu$ mole fatty acid $/ \mathrm{ml}$ packed cells

F-2 $\quad 0.16 \pm 0.06 \mu$ mole fatty acid $/ \mathrm{ml}$ packed cells

$\mathrm{PL}^{*} \quad 1.3 \pm 0.4 \mu$ moles phosphatide $/ \mathrm{ml}$ packed cells

All data are averages of six determinations on cells from three separate donors.

* It should be noted that, if expressed as moles total fatty acid, the value would be double. This would imply equal participation of fatty acids at positions 1 and 2 of the glycerol backbone, which at this stage is not warranted.
TABLE III

Transfer Rates

Amoles fatty acid $/ \mathrm{ml}$
cells per $h r$
Alb-FA to F-1*
F-1 to F-2

All data are averages of six determinations on cells of three separate donors except for F-2 $\rightarrow$ F-1 which is the average of one pair of determinations on one donor.

* All rates were determined after $1 \mathrm{hr}$ of incubation except for Alb-FA $\rightarrow$ F-1 which was determined after 5 min of incubation.

\section{DISCUSSION}

In red cells, where all modes of cell destruction finally involve alterations in membrane structure (25) and where cell aging appears to be related to a gradual reduction in membrane mass (2628 ), the importance of a membrane renewal system is clear.

Efforts to correlate defects of red cell survival or shape $(29,30)$ with the composition of red cell membranes have been relatively unsuccessful (31). Recently metabolic studies with ${ }^{32} \mathrm{P}$ designed to uncover possible differences between normal red cells and those with defective membrane function have been reported $(32,33)$. The further possibility that similar defects may be correlated with anomalies in the renewal of the fatty acids of membrane phosphatides prompted us to these studies. In these experiments with normal cells, a system has been developed in vitro to allow exploration of the dynamics of red cell fatty acid turnover in disease states.

In examining the data in Fig. 3, it appears that the initial stage of free fatty acid incorporation into erythrocyte membrane is a rapid, energyindependent transfer from binding sites on albumin to those on the erythrocyte membrane. This process is complete within a few minutes and apparently is not limiting for the subsequent reactions (Table III). In addition, it appears to be a true transfer of free fatty acid and not the adhesion of albumin-fatty acid complex to the red cell membrane, as shown by the data with labeled albumin-labeled fatty acid (Fig. 4). Goodman (34) compared the affinity of red cell binding 
sites for fatty acids with the various fatty acid binding sites of albumin. In his experiments, commercial ${ }^{131} \mathrm{I}$-labeled albumin was introduced into the system consisting of red cells and fatty acidloaded albumin. Our reason for reexamining the possibility that the fatty acid-albumin complex per se might be significantly bound to erythrocytes stemmed from the question of possible differences between the labeled albumin used by Goodman and that to which his fatty acids were bound. The present results confirm and extend Goodman's initial observation.

The free fatty acid remaining in albuminextracted labeled red cells (Table I, B) suggests that there is a second pool of cellular fatty acid that is not accessible to albumin. We operationally describe this as a pool "deeper" in the membrane. It should be noted that while this may be indeed anatomically farther from the cell surface, the data do not prove this point; these fatty acids may simply be bound more avidly than they are in F-1 or on albumin.

The data in Fig. 5 suggest that the transfer of free fatty acid into the F-2 pool proceeds from the F-1 pool and is dependent upon cellular energy. Additionally, a precursor-product relationship is strongly suggested between these two pools although the continual removal of fatty acid from F-2 to PL makes definitive interpretation of a precursor-product relationship difficult. Nevertheless, in "pulse-labeled experiments" " typified by the data in Fig. 6, nearly $90 \%$ of the activity in the $\mathrm{F}-1$ fraction appears to pass into or through the F-2 fraction during the time of the experiment.

A similar relationship between fractions F-2 and $\mathrm{PL}$ is demonstrated in Fig. $7 a$ and $b$. Here it is also shown that there is a slight backflow from the "deeper" F-2 pool in addition to a much larger forward flow of fatty acid from F-2 into the phospholipid pool. Energy is apparently necessary for flow from F-2 to both F-1 and PL.

When one employs the data on pool sizes and transfer rates in Tables II and III, some approximate calculations of the cost of the transfer process in terms of ATP available from red cell glycolysis can be made. $1 \mathrm{ml}$ of red blood cells utilizes 2 $\mu$ moles of glucose per $\mathrm{hr}(35)$. This produces 4

\footnotetext{
4 This refers to experiments in which the period of
} initial labeling was $12 \mathrm{~min}$ ( $\frac{1}{8}$ of the total incubation time). $\mu$ moles of lactate per $\mathrm{hr}$ and $4 \mu$ moles of ATP per hr, assuming that the pathway involving 2,3diphosphoglycerate is not significantly operative (36). Various authors estimate that $7-30 \%$ of this energy is used in maintaining the sodiumpotassium ion pump $(37,38)$. This leaves a minimum net unassigned energy production of approximately $3 \mu$ moles of ATP per $\mathrm{ml}$ of cells per hr. The figure we have obtained for the final rate of palmitic acid transfer from F-2 into phospholipid is $30 \mathrm{nmoles} / \mathrm{hr}$. This corresponds to a turnover of the fatty acids of phosphatidylcholine and phosphatidylethanolamine of approximately $2 \% / \mathrm{hr}$ or $50 \% /$ day. One may assume that the acylation of lysolecithin requires 2 moles of $\sim \mathrm{P}$ to activate 1 mole of fatty acid since AMP is produced in the formation of acyl CoA (39). The net cost of the reaction F- $\rightarrow$ PL is a total of 60 nmoles of $\sim P$ per hr per $\mathrm{ml}$ of cells. According to Oliveira and Vaughn (1) and Mulder, de Gier, and Van Deenen (40), palmitic acid which is used in these experiments is approximately six times less active in the acylation of lysolecithin than linoleic acid, but approximately two times more active than stearic and oleic acids. From the distribution of the fatty acids of red cell lecithin (41), it may be calculated that a further factor of approximately 2.5 -fold in the over-all rate of this reaction may be invoked. This factor gives an estimated cost of the last stage of phosphatide fatty acid renewal in the mature red cell of 150 nmoles of $\sim \mathrm{P}$ per $\mathrm{hr}$, or approximately $5 \%$ of the cellular energy. It should be reiterated that this figure represents only the final stage of incorporation and that energy requirements of antecedent stages of fatty acid transfer (i.e. F-1 $\rightarrow F-2$ ) have not yet been evaluated. We have shown that F-1 $\rightarrow F-2$ is indeed dependent upon metabolism. If the assumption is made that this process operates at about the same energy cost as does F-2 $\rightarrow$ PL, then we may speculate that the over-all requirement for incorporation of plasma fatty acids into membrane lipids is about $10 \%$ of the metabolic energy.

We have recently noted a 4-fold increase in the rate of the incorporation of fatty acid into $\mathrm{PL}$ in red cell suspensions moderately rich $(12 \%)$ in reticulocytes. This finding suggests that the process of acylation may account for a very significant amount of metabolic activity in these young and active cells. It may also imply a difference in fatty 
acid permeability in the membranes of these cells or a difference in the rate of the F-1 $\rightarrow \mathrm{F}-2$ reactions.

Our data confirm some of the observations made in the recent work of Donabedian and Karmen (7) in which they studied the relative rates of transfer and incorporation of various fatty acids into red blood cells. These authors also found that the initial transfer of fatty acids to the membrane surface was rapid and reversible. In addition, they found that this first step was faster at lower concentrations of albumin. They observed that the extent of final incorporation into phospholipids of specific fatty acids was a function of the concentration of each of those fatty acids in the total cellular free fatty acid pool (F-1 plus F-2 in our scheme). This observation would fit our proposed precursorproduct relationship between the F-2 and PL pools. Additionally, Donabedian and Karmen noted significant incorporation into triglycerides after $3 \mathrm{hr}$ of incubation. Our findings of modest (less than 20\%) incorporation after $1 \mathrm{hr}$ are in accord with this observation.

A consideration of how closely the system studied in vitro represents the normal situation in vivo is pertinent. Tarlov (42), using rat red cells and entirely different methods, has demonstrated the renewal of red cell membrane phospholipids in vivo. In Tarlov's experiments half of the renewal occurred through a passive exchange of lecithin between plasma and cells. $\mathrm{He}$ has also suggested that approximately one-half of the renewal occurs through acylation of lysolecithin. Both he and Elsbach (43) (who used phagocytizing white blood cells in vitro) have presented evidence that the acylation process is considerably augmented by the presence of plasma lysolecithin which, being highly membrane-soluble, diffuses freely into the cell and is rapidly converted into lecithin. In one recent experiment we have noted a 2 - to 3 -fold increase in fatty acid incorporation into $\mathrm{PL}$ with sublytic concentrations of lysolecithin. Recent studies $(44,45)$ suggest that, under the conditions we used, 1 nmole of lysolecithin per $\mathrm{mg}$ of albumin (or approximately 2 nmoles of lysolecithin per $\mathrm{ml}$ of packed cells) might have been added to our system. We were, however, unable to detect lysolecithin in the cell extracts which we studied by thin-layer chromatography.

The lecithin formed from lysolecithin is in much slower equilibrium with plasma than the substrate lysolecithin, which exhibits rapid rates of equilibration (42). One could hypothesize that the red blood cell had developed a "trapping mechanism" both for the lecithin backbone and for plasma free fatty acids, by the acylation system described. The advantages of such a trapping mechanism to a cell that lacks the ability to synthesize either free fatty acids or phosphatides de novo $(46,47)$, and that progressively loses membrane lipid as it ages, are clear. In addition to the advantages to the cell of trapping essential building blocks, this series of reactions would appear to serve as a method of limiting the intramembrane concentration of lysolecithin which is dangerous at high levels (48).

Comparison of the F-2 $\rightarrow$ PL fatty acid incorporation rates which we have found with those given in previous studies is of little value because pool size corrections were not made previously $(1,2)$. The data of Tarlov $(42)$ are amenable to such comparison, however, since he measured incorporation of preformed lysolecithin labeled in the choline moiety. Such a measurement of incorporation does not depend on knowledge of the size of fatty acid pools antecedent to final acylation. $\mathrm{He}$ found a turnover dependent upon acylation of approximately $1 \% / \mathrm{hr}$ using rat erythrocytes and measuring phosphatidylcholine synthesis alone. Our results of approximately $2 \% / \mathrm{hr}$ for phosphatidylcholine plus phosphatidylethanolamine in humans with somewhat lower amounts of total red blood cell phospholipid appear to be quite comparable.

In the absence of a known chemical pathway, the energy requirements for the F-1 $\rightarrow$ F-2 step are beyond precise calculation. It is interesting to consider, however, from the work of Wittels and Hochstein (49) that carnitine fatty acyltransferase or a similar transferase might be operative at this stage. In preliminary experiments, however, we have found no stimulation of incorporation of free fatty acids into phospholipids in the presence of added carnitine.

Although significant phospholipase A activity has not been demonstrated in erythrocytes, one should consider a possible alternative pathway, i.e., one in which fatty acids could be transferred from $\mathrm{F}-1$ to $\mathrm{F}-2$ by a cycle involving sequential acylation and deacylation of the 1-position of 
lecithin. Waite and Van Deenen (50) have recently found phospholipase $A_{1}$ in liver homogenates. This enzyme hydrolyzes the acyl ester link at the 1-position of lecithin. On subcellular fractionation of the tissue, the enzyme showed a distribution similar to that previously reported for the fragmented plasma membrane (51). Isolated plasma membranes from liver cells incorporate bound unesterified fatty acids into phospholipids more actively than any other cell fraction of this tissue (52). An acylation/deacylation cycle involving the enzyme mentioned above would require the presence of a small quantity of phospholipid which would become labeled even before F-2.

It is possible that the F-1 $\rightarrow F-2$ step may normally limit the extent of over-all phosphatide synthesis. This possibility is suggested by the repeated observation $(1,5)$ that homogenates and ghosts are more active in over-all incorporation of fatty acid than intact cells. One could suppose that the usual membrane limits have been broken and high concentrations of free fatty acid can be directly presented to the final synthetic pathway. In addition, the data of Wittels and Hochstein (53) and of Jacob and Lux (54) suggest that in prelytic states due to either primaquine treatment or vitamin $\mathrm{E}$ deficiency, the over-all process of fatty acid incorporation into phosphatide is considerably increased. Again this could be due to an "opening up" of the membrane barrier which might effectively circumvent the F-1 $\rightarrow$ F-2 step and allow the F-2 $\rightarrow$ PL step to proceed maximally.

It will be of considerable interest to see if this system of reactions is different in the young red cell and reticulocyte which might well have more active membranes than the population of cells studied here. In this regard it should be recalled that in the isolation of cells a definite bias to older cells was made by removing the top $10 \%$ of red blood cells during repeated washes. It will also be interesting to see if perturbations of this series of reactions exist in congenital hemolytic anemias, thalassemias, and other hemolytic disorders in which cell membrane maintenance appears to be abnormal.

\section{ACKNOWLEDGMENTS}

We are grateful to Dr. Arthur Karmen of the Johns Hopkins Medical School for advice and encouragement in the early stages of this work, and to Dr. Robert Michell of Harvard Medical School for helpful criticism and suggestions.

These studies were supported in part by the U. S. Public Health Service General Research Support Grant to the Peter Bent Brigham Hospital, U. S. Public Health Service Grants Nos. HD 0277 and AI 03260, the Cargill Foundation, and the John A. Hartford Foundation, Inc.

\section{REFERENCES}

1. Oliveira, M. M., and M. Vaughn. 1964. Incorporation of fatty acids into phospholipids of erythrocyte membranes. J. Lipid Res. 5: 156

2. Mulder, E., J. W. O. Van Den Berg, and L. L. M. Van Deenen. 1965. Metabolism of red cell lipids II. Conversions of lysophosphoglycerides. Biochim. Biophys. Acta. 106: 118.

3. Lands, W. E. M. 1960. Metabolism of glycerolipids. II. The enzymatic acylation of lysolecithin. J. Biol. Chem. 235: 2233.

4. Erbland, J. F., and G. V. Marinetti. 1962. In vitro metabolism of lysolecithin. Federation Proc. 21: 295; 1965. The enzymatic acylation and hydrolysis of lysolecithin. Biochim. Biophys. Acta. 106: 128.

5. Mulder, E., and L. L. M. Van Deenen. 1965. Metabolism of red cell lipids. I. Incorporation in vitro of fatty acids into phospholipids from mature erythrocytes. Biochim. Biophy's. Acta. 106: 106.

6. Elsbach, P. 1966. Phospholipid metabolism by phagocytic cells. I. A comparison of conversion of ${ }^{32} \mathrm{P}$ Lysolecithin to lecithin and glycerylphosphorylcholine by homogenates of rabbit polymorphonuclear leukocytes and alveolar macrophages. Biochim. Biophys. Acta. 125: 510 .

7. Donabedian, R. K., and A. Karmen. 1967. Fatty acid transport and incorporation into hurian erythrocytes in vitro. J. Clin. Invest. 46: 1017.

8. Spector A. A., and D. Steinberg. 1965. The utilization of unesterified palmitate by Ehrlich ascites tumor cells. J. Biol. Chem. 240: 3747.

9. Spector A. A., and D. Steinberg. 1966. Turnover and utilization of esterified fatty acids in Ehrlich ascites tumor cells. J. Biol. Chem. 242: 3057.

10. Spector A. A., and D. Steinberg. 1966. Relationship between fatty acid and glucose utilization in Ehrlich ascites tumor cells. J. Lipid Res. 7: 657.

11. 1961. Krebs' Salt Solutions (Krebs and Henseleit). In Biochemists Handbook. Cyril Long, editor. Van Nostrand Company Inc., Princeton. 58.

12. Goodman, D. S. 1957. Preparation of human serum albumin free of long-chain fatty acids. Science. 125: 1296.

13. Folch, J., M. Lees, and G. H. Sloane Stanley. 1957. A simple method for the isolation and purification of total lipides from animal tissues. J. Biol. Chem. 226: 497.

14. Sperry, W. 1955. Lipide analysis. In Methods of Biochemical Analysis. Academic Press Inc., New York. 2: 87 . 
15. Dole, V. P., and H. Meinertz. 1960. Microdetermination of long-chain fatty acids in plasma and tissues. J. Biol. Chem. 235: 2595.

16. Buhler, D. R. 1962. A simple scintillation counting technique for assaying $\mathrm{C}^{14} \mathrm{O}_{2}$ in a Warburg flask. Anal. Biochem. 4: 374.

17. Rose, H. G., and M. Oklander. 1965. Improved procedure for the extraction of lipids from human erythrocytes. J. Lipid Res. 6: 428.

18. Skipski, V. P., R. F. Peterson, and M. Barclay. 1964. Quantitative analysis of phospholipids by thin layer chromatography. Biochem. J. 90: 341.

19. 1957. Methods in Enzymology. S. P. Colowick and N. O. Kaplan, editors. Academic Press Inc., New York. 3: 520.

20. Skidmore, W. D., and C. Entenman. 1962. Two dimensional thin layer chromatography of rat liver phosphatides. J. Lipid Res. 3: 471.

21. Lines, J. G. 1963. Neutral lipids. Quantitative aspects of thin layer chromatography applied to the lipids of biological material. In Biochemical Problems of Lipids. A. C. Frazer, editor. Elsevier Publishing Co., Amsterdam. 17.

22. Lowry, O. H., N. R. Roberts, K. Y. Leiner, M. L. $\mathrm{Wu}$, and A. L. Farr. 1954. The quantitative histochemistry of brain. I. Chemical methods. J. Biol. Chem. 207: 1 .

23. Reif, A. E. 1966. A simple procedure for high efficiency radioiodination of antibodies. Federation Proc. 25: 726.

24. Nathan, D. G., T. G. Gabuzda, and F. H. Gardner. 1963. Liquid scintillation counting of ${ }^{14} \mathrm{C}$-labeled hemoglobin and hemin by a modified Schröniger technique. J. Lab. Clin. Med. 62: 511.

25. Weed, R. I., and C. F. Reed. 1966. Membrane alterations leading to red cell destruction. Am. J. Med. 41: 681 .

26. Munn, J. I. 1958. Studies of lipids in human red cells. Brit. J. Haematol. 4 : 344

27. Van Gastel, C., D. Van Den Berg, J. de Gier, and L. L. M. Van Deenen. 1965. Some lipid characteristics of normal red blood cells of different age. Brit. J. Haematol. 11: 193.

28. Weed, R. I., and C. F. Reed. 1965. The relation of erythrocyte fragmentation to cellular destruction. Blood. 26: 894. (Abstr.)

29. Harris, I. M., T. A. J. Prankerd, and M P. Westerman. 1957. Abnormality of phospholipids in red cells of patients with paroxysmal nocturnal haemoglobinuria Brit. Med. J. 2: 1276.

30. Kates, M., A. C. Allison, and A. T. James. 1961. Phosphatides of human blood cells and their role in spherocytosis. Biochim. Biophys. Acta. 48: 571.

31. Bradlow, B. A., R. Rubinstein, and J. Lee. 1965. Erythrocyte phospholipids: Quantitative thin layer chromatography in paroxysmal nocturnal hemoglobinuria and hereditary spherocytosis. Brit. J. Haematol. $11: 315$.
32. Jacob, H. S., and M. L. Karnovsky. 1967. Concomitant alterations of sodium flux and membrane phospholipid metabolism in red blood cells: studies in hereditary spherocytosis. J. Clin. Invest. 46: 173.

33. Reed, C. F., and L. E. Young. 1967. Erythrocyte energy metabolism in hereditary spherocytosis. $J$. Clin. Invest. 46: 1196.

34. Goodman, D. S. 1958. The interaction of human erythrocytes with sodium palmitate. J. Clin. Invest. 37: 1729.

35. Prankerd, T. A. J. 1961. The Red Cell. Blackwell Scientific Publications Ltd., Oxford. 59.

36. Keitt, A. S. 1966. Pyruvate kinase deficiency and related disorders of red cell glycolysis. Am. J. Med. 41: 762.

37. Solomon, A. K., T. J. Gill, 3rd, and C. L. Gold. 1957. The kinetics of cardiac glycoside inhibition of potassium transport in human erythrocytes. J. Gen. Physiol. 40: 327.

38. Whittam, R. 1964. Transport and Diffusion in Red Blood Cells. The Williams \& Wilkins Company, Baltimore. 150.

39. Kornberg, A., and W. E. Pricer, Jr. 1953. Enzymatic synthesis of the coenzyme A derivatives of long chain fatty acids. J. Biol. Chem. 204: 329.

40. Mulder, E., J. de Gier, and L. L. M. Van Deenen. 1962. Selective incorporation of fatty acids into phospholipids of mature red cells. Biochim. Biophys. Acta. 70: 94.

41. Hanahan, D. J., R. M. Watts, and D. Pappajohn. 1960. Some chemical characteristics of the lipids of human and bovine erythrocytes and plasma. J. Lipid Res. 1: 421.

42. Tarlov, A. R. 1966. Lecithin and lysolecithin metabolism in rat erythrocyte membranes. Blood. 28: 990. (Abstr.)

43. Elsbach, P. 1967. Stimulation of lecithin synthesis from medium lysolecithin during phagocytosis. $J$. Clin. Invest. 46: 1052. (Abstr.)

44. Switzer, S., and H. A. Eder. 1965. Transport of lysolecithin by albumin in human and rat plasma. J. Lipid Res. 6: 506.

45. Elsbach, P. 1967. Metabolism of lysophosphatidyl ethanolamine and lysophosphatidyl choline by homogenates of rabbit polymorphonuclear leukocytes and alveolar macrophages. J. Lipid Res. 8: 359.

46. Marks, P. A., A. Gellhorn, and C. Kidson. 1960. Lipid synthesis in human leukocytes, platelets and erythrocytes. J. Biol. Chem. 235: 2579.

47. Pittman, J. G., and Martin, D. B. 1966. Fatty acid biosynthesis in human erythrocytes: Evidence in mature erythrocytes for an incomplete long chain fatty acid synthesizing system. J. Clin. Invest. 45: 165.

48. Dawson, R. M. C. 1966. The metabolism of animal phospholipids and their turnover in cell membranes. Essays Biochem. 2: 83

49. Wittels, B., and P. Hochstein. 1967. The identification 
of carnitine palmityltransferase in erythrocyte membranes. J. Biol. Chem. 242: 126.

50. Waite, M., and L. L. M. Van Deenen. 1967. Hydrolysis of phospholipids and glycerides by rat-liver preparations. Biochim. Biophys. Acta. 137: 498.

51. Coleman, R., R. M. Michell, J. B. Finean, and J. M. Hawthorne. 1967. A purified plasma membrane fraction isolated from rat liver under isotonic conditions. Biochim. Biophys. Acta. 135: 573.
52. Higgins, J. A., and C. Green. 1967. The entry of palmitic acid into rat liver cells. Proceedings of the Biochemical Society, June, 1967. 14.

53. Wittels, B., and $P$. Hochstein. 1966. The effect of primaquine on lecithin metabolism in human erythrocytes. Biochim. Biophys. Acta. 125: 594.

54. Jacob, H., and S. Lux. 1967. Mechanism of oxidant hemolysis in vitamin $\mathrm{E}$ deficiency. Clin. Res. 15: 280. (Abstr.) 